\title{
Fiction Film and History
}

The idea of a semiotic representation of the past is deeply rooted in film theory. ${ }^{1}$ In my reflections on the basic features of histospheres in the first section of this chapter, I therefore make reference to a classic semiological model according to which a film's aesthetic and narrative production of meaning is determined by its specific arrangement of signs. I draw parallels to debates within historical studies that have enabled a reassessment of fiction film as a historiographical medium and mode of conceptualizing history. The second section discusses theories of the relation between fiction film and history. Building on the semiological and poetological considerations set out in the first section, I posit a genre of popular fiction film defined by its referential relation to historical events, individuals, and lifeworlds. Historical films, I show, are constituted by a specific constellation of aesthetic and narrative devices. Concepts of credibility and authenticity are developed and constantly transformed in a process of negotiation between filmmakers, films, and spectators. In the third section, I argue that this is less a matter of incontrovertible factual accuracy than of generating a feeling of authenticity. As well as taking stock of the existing literature on film and history, this chapter aims to develop a terminological apparatus for describing the conceptual core of the historical film.

R. Greiner, Cinematic Histospheres, https://doi.org/10.1007/978-3-030-70590-9_2 


\section{Poetics and Semiotics}

A tall barbed wire fence, border signs, barriers, no man's land-the montage at the start of Helmut Käutner's SKY WITHOUT STARS can be understood as a narrative organization of signs referring to historical states of affairs and their temporal and spatial coordinates. Consequently, semiology can-all epistemic and other limitations notwithstanding-make a contribution to a cartography of histospheres (Figs. 2.1, 2.2, 2.3, and 2.4). ${ }^{2}$

Viewed through the lens of semiology, the concept of the histosphere is closely related to Russian semiotician Jurij Lotman's notion of the "semiosphere." Based on Vladimir Vernadsky's concept of the biosphere, the semiosphere is a model of a semiotic space that is both "the result and the condition for the development of culture." Every "language" (which for Lotman explicitly also includes cinematographic expression) is immersed in a semiosphere with which it stands in a close reciprocal relation. ${ }^{4}$ The semiosphere of a "language" is in turn surrounded by other semiospheres, which are always connected to a culture's total semiotic

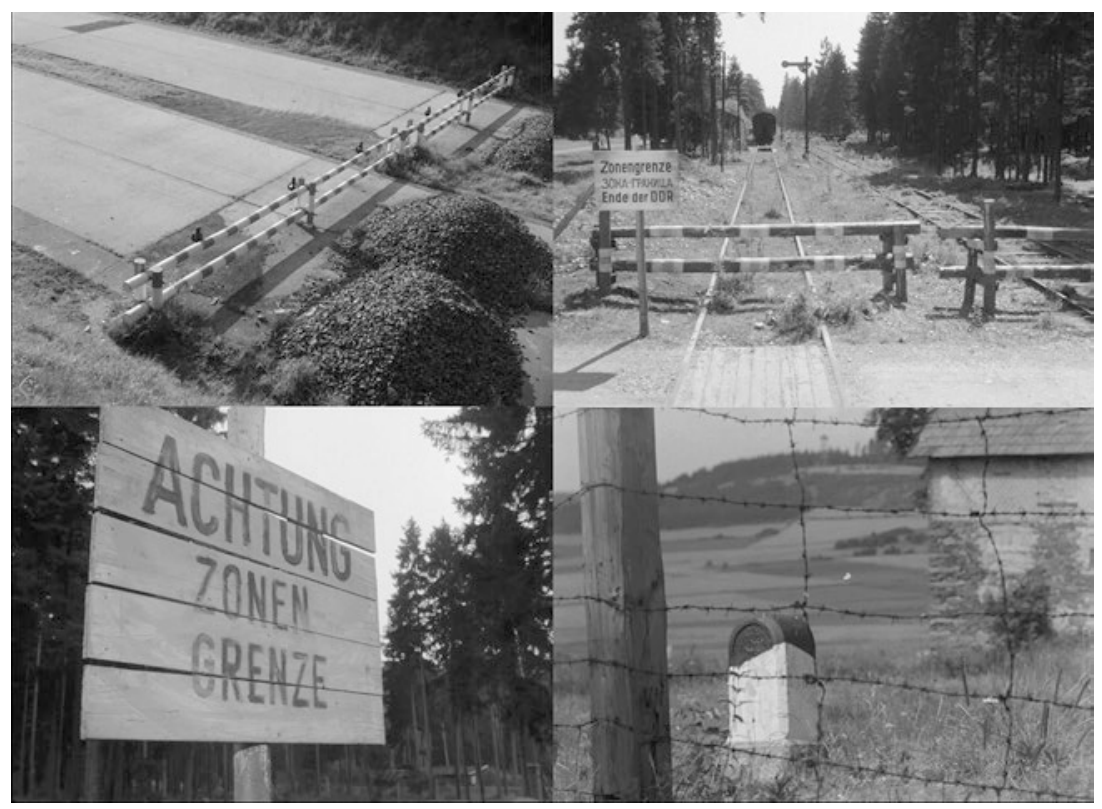

Figs. 2.1-2.4 Narrative organization of signs in SKY WITHOUT STARS 
space. ${ }^{5}$ History and fiction film, I argue, are closely interwoven within this semiotic fabric. This connection has existed since the invention of motion pictures, which has implications for our understanding of both history and film. Film projection as it were makes the past immediately present, drawing (to quote film scholar Gertrud Koch) on the "camera's ineluctable recording function" and the "diegetic function of the moving image." Regardless of whether a film is categorized as documentary or fictional, this process can be understood in terms both of documentation and of artistic arrangement and play. Although Koch does not call for the distinction between documentary and fiction film to be erased, she does suggest that the relationship between film and history is largely independent of this categorization. ${ }^{7}$

The modern distinction between fiction and nonfiction is relatively new. In ancient and medieval times, there was no sharp separation between poetry/literature and history. ${ }^{8}$ It was only with Romanticism's aesthetics of creativity that poetry came to be defined as the sphere of the "marvelous" (das Wunderbare), the "ideal," and the "imagination" of an inventive poet. ${ }^{9}$ However, one feature still shared by historical and creative writing is the "narrative composition of their elements" tional elements are fused together in the mode of narration. This is the basis of Hayden White's theory of history, developed against the backdrop of the linguistic turn. ${ }^{11}$ White maintains that history is structured by unconscious linguistic patterns of perception: To quote Axel Rüth's summary of White's theory, the historian "generates meaning by synthesizing disparate 'raw material' (individuals, actions, events, etc.) into a meaningful narrative."12 Film scholar Bernhard Groß describes how White's Metahistory attempts "to reconstruct the rhetoric and genres of nineteenthcentury historiography and philosophy of history, that is to say, to distinguish history according to the rules of literary and rhetorical models."13 White draws a connection between historical writing and literary methods, thereby calling the objectivity of history into question. ${ }^{14}$ Groß identifies in this view "the constructivist supposition that history too is unable to get around the mediality of its objects, which means that facts do not exist or cannot be known prior to their representation but are themselves a product of this representation." 15 This implies that fictional films can also be a mode of historical expression. If, however, the knowability of facts is necessarily tied to their mediality, this will be a crucial differentiating factor, and so any attempt to equate written history and historical films based on White's theory will prove unworkable. For example, while film scholar 
Eleftheria Thanouli's argument that historical films are essentially "magnified miniatures" of written history may apply at the narrative level that she is investigating, a phenomenologically based theory of mediated historical experience will make the limits of her approach apparent. ${ }^{16}$ Below, I shall show that the relation between filmed and written history is one of referentiality and mutual complementarity, rather than similarity.

White's thesis that historical writing is necessarily narrative ${ }^{17}$ also invites closer attention to cinematic modes of narrating history. The montage of visual signifiers of the inner German border at the start of SKY WITHOUT STARS, in combination with the dramatic orchestral score and the explanatory voice-over, creates a meaningful narrative. Like a historian, the film selects certain elements from the countless events of the past and weaves them into a historical narrative. The deliberately composed series of images at the start of SKY wITHOUT STARS is linked together by montage and the continuous soundtrack. The impassioned voice-over does not simply explain that the inner German border exists, but asserts that it originates in "discord and hate." As the historian Siegfried Mattl observes of history in general:

History in the modern sense-and the regulative idea of comprehensible, and consequently "necessary," developmental processes as objects of historiographical knowledge-comes about only through being embedded in series and chains of events, and hence in a way of thinking based on the logic of cause and effect. ${ }^{18}$

For historical films, this entails that the narrative logic must necessarily point beyond its own boundaries. In order to be perceived as historical, it refers to other historical narratives that have shaped our conceptions of the historical period in question. In semiotic terms, the elements of films involved in this process of historical reference are signifiers of signifiers ${ }^{19}$; narratively organized significations of other narratively organized significations that in turn refer to the signified-the past. Actual historical reality necessarily remains imaginary; films and other forms of history can merely represent the past, they cannot "restore" or reproduce it. Like the medium of film in general, historical films also generate meaning through a process of signification. In film, the signified has "a conceptual character; it is an idea. It exists in the viewer's memory and the signifier merely actualizes it." ${ }^{20}$ Historical referentiality can be understood analogously. By systematically arranging audiovisual signs into a histosphere, historical films allow 
a "bygone world" 21 to be imagined, though this requires a complex process of negotiation between film and spectator. Koch suggests that it is precisely the artificial, constructed character of the "cosmos of signs" that makes a historical film so immersive:

One might think that it is precisely the concretist character of the sets, the artificiality [Kulissenhafte] of the painted and sawn scenery, that constantly signals to spectators that this is an invented story. But the opposite appears to be the case: The more symbolic and self-contained the aesthetic cosmos of signs that envelop the spectators, the more readily they will succumb to the myth. ${ }^{22}$

The credibility and immersive potential of a histosphere are, thus, determined not by factual accuracy or naturalist faithfulness to reality, but by the homogeneity and consistency of its cosmos of signs. ${ }^{23}$

For a finer-grained analysis of the connection between cinematic signs and conceptions of history, it is worth turning our gaze to the early film theory of Béla Balázs. His deliberations on physiognomy explicitly distinguish between a deliberately crafted and styled film aesthetic, and a striving for realistic reproduction. ${ }^{24}$ Balázs believes that, by attending to physiognomy, cinema can open up a new dimension; aesthetic devices such as close-ups make the world shown on screen our own. ${ }^{25}$ Although this approach is still strongly influenced by a poetological understanding of film, ${ }^{26}$ at a semiological level Balázs does also create the theoretical foundations for a histosphere that does not merely represent historical worlds but creates and gives structure to them in the first place. His approach remains helpful for a better understanding of histospheres, as shown by a sequence from SKY WITHOUT STARS.

When Anna enters her parents-in-law's home after her illegal border crossing, the camera follows her gaze. On the wall is the portrait of a young man in a Wehrmacht uniform. The iron cross, artificial flowers, and black ribbon on the frame make clear that it is a picture of the couple's son, Anna's husband, who died in the war. We hear the rumble of an engine, and the photograph starts to vibrate; it almost looks like it will fall from the wall. A reaction shot shows Anna briefly pause and then turn away (Figs. 2.5 and 2.6). This audiovisual metaphor may evoke associations with air raids, death, and destruction. As in Balázs's writings on the physiognomy of film, emotional impressions are conveyed using audiovisual figurations that make the filmic world itself into a means of affective 


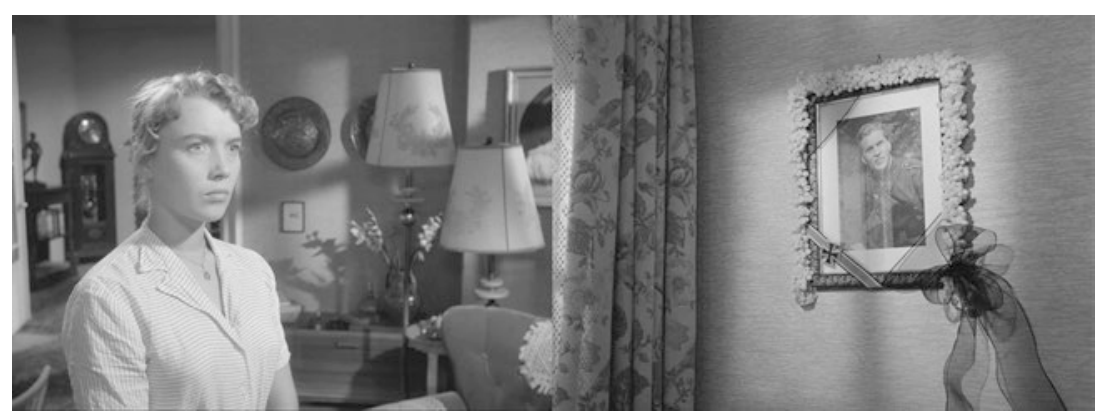

Figs. 2.5-2.6 Audiovisual metaphor for the war in SKY WITHOUT STARS

expression. However, while in the 1950s this device would have been able to awaken German audiences' memories of their own lived experiences, for modern spectators it can only be comprehended indirectly, by reference to other audiovisual or written representations. What this shows is that filmic signs "evolve." ${ }^{27}$ Which of the references in the historical cosmos of signs spectators will actually pick up on depends on their individual historical experiences and knowledge.

Cinema's access to the past can also be conceived in terms of Jacques Rancière's philosophy of history, with histospheres comprising a specific poetics of history that separates film from other arts. ${ }^{28}$ According to Rancière, the poetic relationship to the past mobilizes a "history-forming power" that allows film to contribute to the writing of history. On this construal, film is carrying out the aesthetic program of Romanticism: "the reconciliation of feeling and intellect, individual and universal, subjectivity and community." 29 A histosphere utilizes this potential of the cinematic medium in order to audiovisually model a historical world. Although film is a product of the late nineteenth century, the modern cinematic poetics of history goes beyond Romantic thinking. Like historiographic texts from the second half of the twentieth century, which make their method explicit and thereby possess a critical self-reflexivity, cinematic representations of history prompt us to think about our own historical conceptions. ${ }^{30}$ This potential is already inherent in the cinematic perspective on the world; we can refer here again to Balázs's theory, which (according to Matthias Hein) is intimately bound up with the idea of " "expanding' our access to the world by means of the camera"; cinema not only fosters "greater awareness of the world around us" 31 but, in the case of the 
historical film, also a relational, reflexive awareness of the connection between history and the present. The tension between direct, immersive participation in a film's historical world and the evolution of the signifiers used in the film keeps our perceptions of the depicted historical era labile and open. When we watch the above-described sequence from SKY WITHOUT STARS today, different historical levels are layered one on top of the other. The film's cosmos of signs comprises both the diegetic present and the diegetic past (the time of the Second World War) as well as the cinematic conventions of the mid-1950s that are evident in the film; the conceptions of history formed from this histosphere, and its own historicity, are dependent on our sensuous experience.

\section{Historical Films}

A large hall behind glass-paned double doors, a counter with bar stools, a display cabinet - in a series of almost monochromatic images, the opening sequence of KU'DAMM 56 models the lobby of the Galant dance school. Spacious musical tones create a spirited-away atmosphere. A young woman steps into shot, expectantly opens a box, and takes out a new pair of sneakers. Then she is flying through the air, swirled around by her dance partner (Figs. 2.7, 2.8, 2.9, and 2.10). In film, writes Balázs, even "the most intimate human experiences can be the result and reflection of great historical events." 32 So too at the start of Sven Bohse's TV series. The focus of this historical experience is not some momentous geopolitical decision, but Monika Schöllack competing in “Berlin's first rock ' $n$ ' roll championships."

According to film scholar Jonathan Stubbs, this historical reference is enough to classify KU'DAMM 56 as a historical film, a concept that Stubbs defines very broadly. He classes as historical cinema all "films which engage with history or which in some way construct a relationship to the past."33 The historian Pierre Sorlin prefers a more restrictive semiological approach and suggests that the criterion for whether a film belongs to the genre should be whether it contains signifiers that allow us to identify it as being set in a particular historical period. ${ }^{34}$ In KU'DAMM 56 , such signifiers include the interior of the dance school and the costumes worn by the characters. Sorlin emphasizes that historical films are concerned less with accurately reproducing the past than with establishing relations. ${ }^{35}$ Robert Burgoyne likewise considers it a constitutive feature of historical films that they bring the past into dialogue with the present. ${ }^{36}$ Burgoyne also stipulates that the 


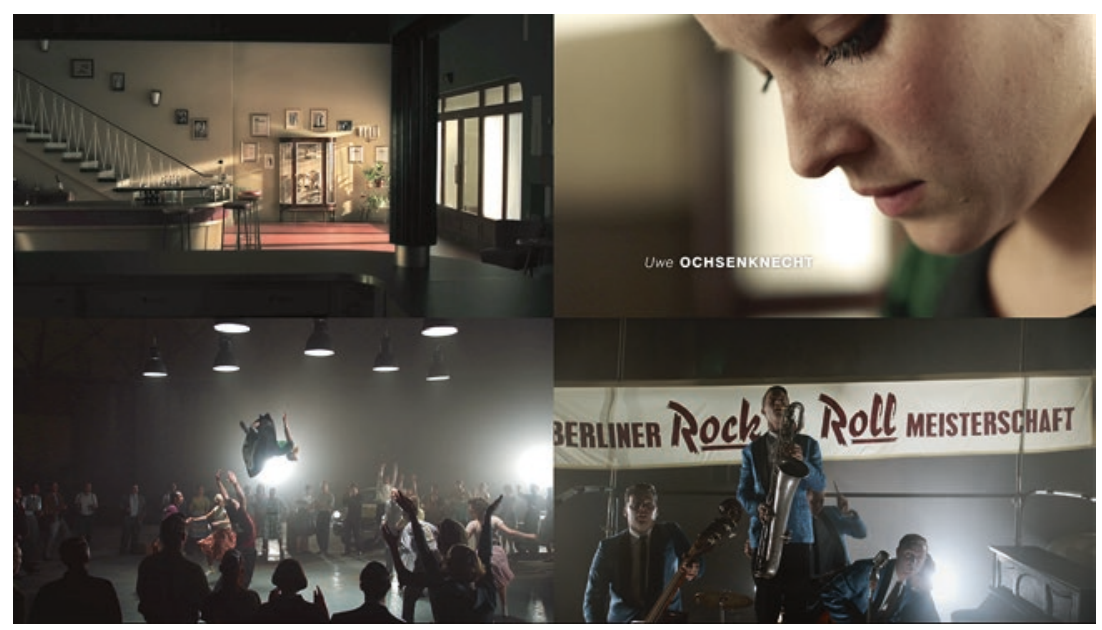

Figs. 2.7-2.10 A personalized historical experience in КU'DАмм 56

action must be based on documentable historical events (by contrast with costume dramas). ${ }^{37}$ Robert Rosenstone adds the further condition that a historical film "intersects with, comments upon, and adds something to the larger discourse of history." 38

All these approaches assume that film is able to represent history. By contrast, media scholar André Wendler suggests that historical films cannot simply invoke, reference, cite, or relate to "history," but must instead "create interfaces between the complex dispositif of the 'historical film' and the no less complex media cluster of "history." "39 What Burgoyne describes as cinema's reenactment of historical periods ${ }^{40}$ is thus (to repeat my opening thesis) based not so much on representation but rather on audiovisual modeling and figuration of a historical world, which in turn enables an immediate experience of history. As a definition of the "historical film" genre, I therefore suggest that a histosphere functions as the core of the "communicative pact" 41 between filmmaker, film, and spectator. As an aesthetic-narrative construction, it not only determines the film's relation to history, but also constitutes a formal criterion that allows historical films to be distinguished from other genres.

Historical films are generally considered highly significant for our conceptions of the past. Koch describes film as a powerful social institution 
that uses both documentary and fictional representations to create imaginaries that have been of undeniable significance in the history of mentalities, at least insofar as this history can be grasped in terms of the forms and contents of social memory. ${ }^{42}$

Simon Rothöhler goes even further, claiming that films themselves "produce and furnish us with historical knowledge that, were it not imparted through the aesthetic medium of film, would be unavailable to us (at least in that form)." ${ }^{43} \mathrm{He}$ attributes this capacity to film's "amateur" status, as manifested in its aesthetics. ${ }^{44}$ In fact, form and content, audiovision, and conceptions of history cannot be disentangled. A histosphere is not just a tool or medium for communicating history; it must be experienced. To put it another way: The histosphere offers a discrete mode of historical thought. ${ }^{45}$ At the same time, it also always interacts with the period in which the film was made. ${ }^{46}$ When we travel back to the $1950 \mathrm{~s}$ with Monika Schöllack (Sonja Gerhardt) in KU'DAMM 56, we encounter a subjectivized figuration of a historical world, composed of images and sounds, from the perspective of 2016. The readings and conceptions of history that we can derive from a film are thus also dependent on the historical horizon against which its histosphere was constructed.

However, historical films' special relationship to the past has also made them the target of criticism. Siegfried Kracauer, for instance, complains that the medium of film depicts the past anachronistically by imposing modern aesthetics. ${ }^{47}$ Conversely, Koch claims that the aesthetic devices of cinema "are so bound up with modern perceptions of time and space, of fragmentation and discontinuity" that they can only be fused into historical representations "at the cost of aesthetic regression." 48 On Koch's view, a historical film can only achieve its effect by denying the historicity of its own perception. ${ }^{49}$ However, Kracauer's criticism is primarily aimed at more historically distant periods when the medium of film did not yet exist. His objection can instead be understood as a general criticism of history per se that could also be extended to modern historiographical publications whose methods of exposition were (analogously to the case of cinema) not fully developed during the period of time they are about. The same lack of specificity applies to Benjamin Moldenhauer's "unease about films that tell stories of the historical past while remaining within the conventional framework of genre cinema." ${ }^{50}$ Although Moldenhauer, by contrast with proponents of apparatus theories, ${ }^{51}$ does not believe that spectators are directly manipulated, his unease is based on reservations of 
a very general sort that other film genres must also contend with. While sweeping criticisms such as "formulaic characters" and an "unreflective evocation of empathy" 52 might well apply for certain films, there are many other examples where they do not and where a histosphere enables a nuanced negotiation of historical meaning on the basis of film experience in which the spectator is included as an actively thinking subject. Films like SKY WITHOUT STARS, YEARS OF HUNGER, and KU'DAMM 56 engage with many historical discourses of the 1950s, such as the confrontation with the Nazi past, the division of Germany, or the fight for gender equality. They all adopt an empathy-driven perspective that is, by and large, tied to the characters; but it is precisely because the spectators are immersively, emotionally absorbed that the historical discourses addressed in the films will continue to work on them even after watching.

\section{The Authenticity Feeling}

We see a jetty. In the background is a low building, perhaps a cafe. Between the jetty and the building are trees and tables laid in white linen, over which a string of lights is hanging. Jutta Brückner's YEARS OF HUNGER opens with a shot of this timeless setting, presented in high-contrast black and white. A first-person narrator reflects on her life in a soft-spoken voice-over. As she speaks, long, drawn-out tone sequences play. The film cuts to an empty rowing boat, besides which an empty drinks can is floating in the water. "And I forced myself to remember"- the voice-over takes us on a journey through time. The facade of a large apartment block fills the screen, and the camera moves across from window to window. Concurrently with the cut to the apartment block, the narrator's voice changes. Now far younger, she reads from a book with gentle emphasis. On-screen text reveals that the year is 1953 (Figs. 2.11 and 2.12).

Filmic representations of the past feel authentic if they are able to offer us a "credible historical experience [Erlebnis]." ${ }^{53}$ To describe this phenomenon, Mattias Frey has coined the notion of an "authenticity feeling"-the "sensation of a media-produced, purportedly successful historicity." 54 In YEARS OF HUNGER, the narrative layering of different periods of time, as an integral part of the histosphere, not only draws attention to the film's construction, but also conveys a sense of authenticity. The narratorial voice, the camera's observing stance, the filming in black and white, and the on-screen text with the year serve as authentication strategies and foster a documentarizing mode of reception. ${ }^{55}$ The histosphere 


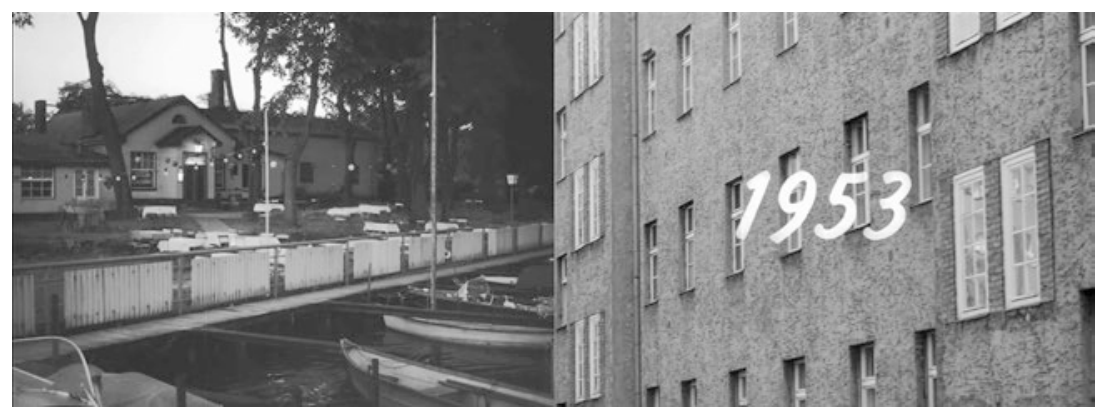

Figs. 2.11-2.12 Cinematic time travel in YeARS OF HUNGer

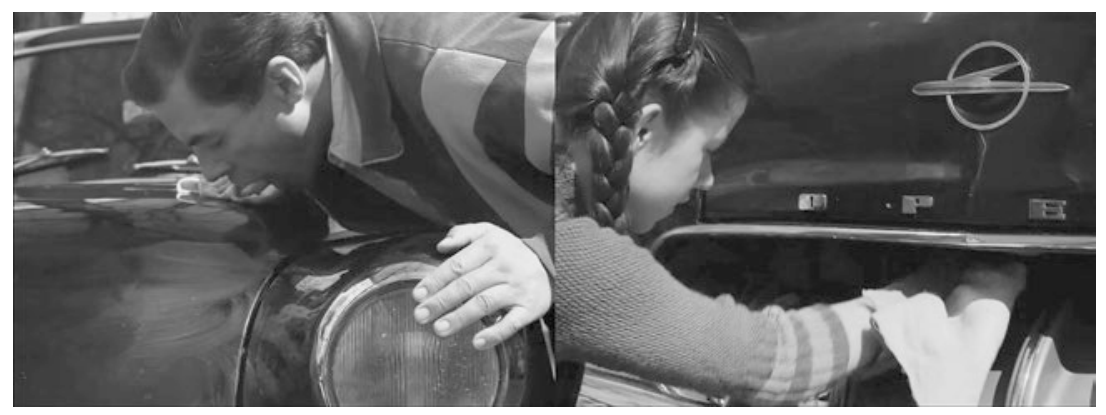

Figs. 2.13-2.14 The car as status symbol in YEARS OF HUNGER

combines these audiovisual devices with the film's "reality effect." 56 When we travel back with the protagonist to the time of her youth, we feel like we are coming into contact not with a media representation but with the past itself. To achieve this effect, audiovisual details, such as the architecture, scenery, and costumes, are used to mark out the histosphere as a historical world. ${ }^{57}$ Vincent Bisson refers to such details as "historical signifiers." ${ }^{58}$ Historical signifiers can include the way characters act and comport themselves, the depicted social milieu, cultural practices, and media and its content. Iconic historical signifiers that are closely associated or even equated with a particular time are especially effective. In YEARS OF HUNGER, for instance, an extended close-up in which the young Ursula (Sylvia Ulrich) and her parents (Britta Pohland and Claus Jurichs) studiously polish the family's new car emphasizes its importance as a status symbol (Figs. 2.13 and 2.14). The car, an Opel Olympia Rekord, can be 
easily dated to the early 1950s thanks to the voluminous design with lots of chrome parts, inspired by American models such as the Chevrolet Bel Air.

Another strategy for generating a feeling of authenticity is to incorporate historical footage into the fictional action. Such sequences possess the "that-has-been" quality that Roland Barthes ascribes to photography. ${ }^{59}$ In YEARS OF HUNGer, the Communist Party ban introduced in West Germany on August 17, 1956, is depicted using archival footage of clashes between police and demonstrators (Figs. 2.15 and 2.16). A voice-over by the retrospective narrator connects the sequence to the fictional action of the histosphere. However, we remain fully aware that the images and soundsafter the voice-over we hear a speech by then interior minister Gerhard Schröder (not to be confused with the later chancellor of the same name) - once served another purpose. Film scholar Jaimie Baron terms this the "archive effect." ${ }^{60}$ According to Baron, the use of archival material creates a feeling of the immediate presence of history and awakens a desire for direct, affective contact with the past. ${ }^{61}$ The archive effect makes use of our yearning for the past, and can engender feelings of nostalgia. ${ }^{62}$ However, Baron stresses that this is merely a potential effect, not an inevitable one, and says that the precise effect of using archive footage will depend on the interaction between film and spectator. ${ }^{63}$ It could bring us uniquely close to the past, but could equally well be perceived as an artificial insertion or interruption. Koch attributes this heterogeneous effect to the dissonance between the archival material and the film in which it is inserted:

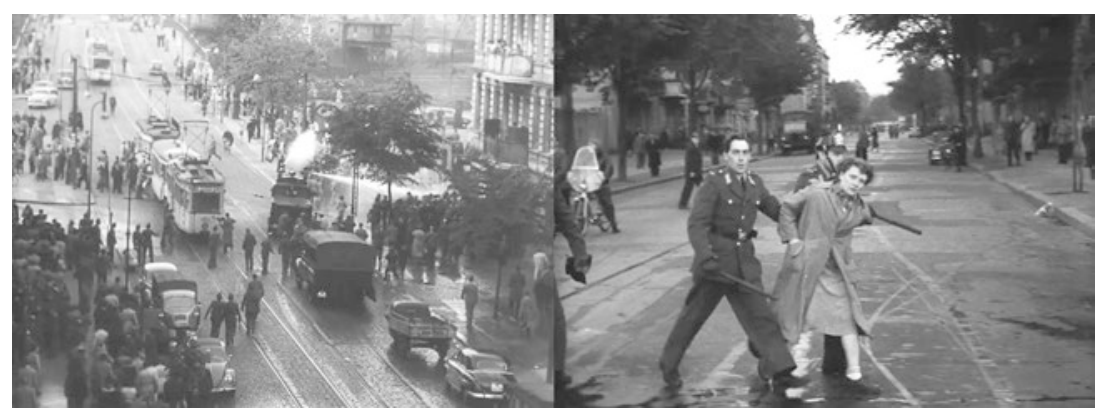

Figs. 2.15-2.16 Use of archival footage in YEARS OF HUNGER 
The film spectator regards as real above all anything that gives the impression of reality; by contrast, they will not be very impressed by anything that disrupts, rather than conforms to, the medium's illusory character. Accordingly, it will not necessarily be historical images that themselves make history, that shape our picture of history. ${ }^{64}$

Through its interaction with the histosphere's immersively lived spatiotemporal structure, modeled out of filmic figurations, the archival material develops a hybrid character. Integrating the material into the film's audiovisual fabric and narrative logic allows it to fuse with the film. But at the same time it remains to some degree a foreign body that can sometimes disrupt the living, immersive encounter with the film. In YEARS OF HUNGER, the archival material falls short of the "medium's illusory character" due above all to the lack of sound; the mute images are accompanied merely by the interior minister's speech. The sequence feels like a documentary interlude, during which the immersive historical world is paused. Nonetheless, the inclusion of the footage heightens the feeling of authenticity. The archive effect makes it seem possible to grasp history directly, and so the footage contributes to a "credible historical experience." ${ }^{5}$ This tension between historical film images and the fictional elements of the histosphere makes one thing clear above all: In historical films, the authenticity feeling is fundamentally dual in nature, involving two, interrelated aspects - a feeling of credible experience and a feeling of credible historical referentiality.

\section{Notes}

1. See Gertrud Koch, "Nachstellungen: Film und historischer Moment," in Eva Hohenberger and Judith Keilbach (eds.), Die Gegenwart der Vergangenheit: Dokumentarfilm, Fernsehen und Geschichte, Berlin 2003, p. 226.

2. Roland Barthes observes that "film cannot be defined as a pure semiological field," since it "cannot be reduced to a grammar of signs." Roland Barthes, "The Problem of Signification in Cinema," in his Signs and Images: Writings on Art, Cinema and Photography, London 2016, p. 22.

3. Yuri [Jurij] M. Lotman, Universe of the Mind: A Semiotic Theory of Culture, Bloomington and Indianapolis 1990, p. 125.

4. Ibid.

5. Ibid.

6. See Koch (2003, p. 226). 
7. For discussion see Bernhard Groß, Die Filme sind unter uns: Zur Geschichtlichkeit des frühen deutschen Nachkriegskinos: Trümmer-, Genre-, Dokumentarfilm, Berlin 2015, p. 53.

8. See Margrit Tröhler, "Filmische Authentizität: Mögliche Wirklichkeiten zwischen Fiktion und Dokumentation," montage AV 13:2, 2004, p. 157.

9. Dietrich Scheunemann, "Fiktionen-auch aus dokumentarischem Material': Von Konstruktionen der Geschichte in Literatur und Film seit den sechziger Jahren," in Hartmut Eggert, Ulrich Profitlich, and Klaus R. Scherpe (eds.), Geschichte als Literatur: Formen und Grenzen der Repräsentation von Vergangenheit, Stuttgart 1990, pp. 296-297, and Tröhler (2004, p. 157).

10. Tröhler (2004, p. 157).

11. On the linguistic turn, see Georg G. Iggers, "Die kulturelle und die linguistische Wende," in his Geschichtswissenschaft im 20. Jahrhundert, Göttingen 2007.

12. Axel Rüth, Erzäblte Geschichte: Narrative Strukturen in der französischen Annales-Geschichtsschreibung, Berlin and New York 2005, p. 18.

13. Groß $(2015$, p. 55$)$.

14. Ibid.

15. Ibid.

16. Eleftheria Thanouli, History and Film: A Tale of Two Disciplines, New York and London 2019, p. 98.

17. Hayden White, "The Question of Narrative in Contemporary Historical Theory," History and Theory 23:1, 1984, pp. 1-33.

18. Siegfried Mattl, "Populare Erinnerung: Zur Nahbeziehung von Film und Geschichte," Nach dem Film 15: Das Unsichtbare Kino, 2017, https:// nachdemfilm.de/issues/text/populare-erinnerung (last accessed May $1,2020)$.

19. This is to treat film as analogous to writing, which-according to Jacques Derrida-as a signifier of the signifier comprehends language and whose "literal" meaning consists in metaphoricity. See Jacques Derrida, Of Grammatology, Baltimore 2016, pp. 7, 15.

20. Barthes $(2016$, p. 30).

21. Koch (2003, p. 225).

22. Ibid. Myth is understood here in the sense of Barthes's definition of a "second-order semiological system," as an articulation of an unconscious collective meaning. See Barthes's essay "Myth Today” in A Barthes Reader, London 1993, p. 99.

23. Gertrud Koch concludes from this that "a world constituted wholly by signs" is a mythical world and thus generates mythical conceptions of history. See Koch (2003, p. 226). 
24. Béla Balázs, Visible Man, in Béla Balázs: Early Film Theory, New York and Oxford 2010, p. 44.

25. Matthias Hein, $Z u$ einer Theorie des Erlebens bei Béla Balázs, Würzburg 2011, p. 158.

26. See for instance: "The hidden pattern of angles, the physiognomy of setups touch off the association of our ideas and conjure up thoughts, moods and emotions, as metaphors do in poetry." Béla Balázs, Theory of the Film: Character and Growth of a New Art, Scotts Valley 2015, p. 112.

27. Barthes (2016, p. 25).

28. Jacques Rancière, "Die Geschichtlichkeit des Films," in Hohenberger and Keilbach (2003, pp. 230-246).

29. Groß $(2015$, p. 65$)$.

30. "A cinematographic reading of history presents the historian with the problem of his own reading of the past." Marc Ferro, Cinema and History, Detroit 1992, pp. 19-20.

31. Hein $(2011$, p. 12).

32. Balázs $(2015$, p. 268).

33. Jonathan Stubbs, Historical Film: A Critical Introduction, New York 2013, p. 19.

34. Pierre Sorlin, The Film in History: Restaging the Past, Oxford 1980, p. 20.

35. Ibid., p. 21.

36. Robert Burgoyne, The Hollywood Historical Film, Malden, MA, 2008, p. 11.

37. Ibid., pp. 3-4.

38. Robert A. Rosenstone and Constantin Parvulescu (eds.), A Companion to the Historical Film, Malden, MA, 2013, p. 1.

39. André Wendler, Anachronismen: Historiografie und Kino, Paderborn 2014 , p. 19.

40. Burgoyne (2008, p. 11$)$.

41. The definition of genre as a communicative pact is taken from Francesco Casetti. See Francesco Casetti, Communicative Negotiation in Cinema and Television, Milan 2002, pp. 21-36.

42. Koch (2003, p. 219).

43. Simon Rothöhler, Amateur der Weltgeschichte: Historiographische Praktiken im Kino der Gegenwart, Zurich 2011, p. 9.

44. Ibid., p. 10.

45. See Robert A. Rosenstone, "The History Film as a Mode of Historical Thought," in Rosenstone and Parvulescu 2013, pp. 71-87.

46. Koch $(2003$, p. 226).

47. Siegfried Kracauer, "Der historische Film," in Siegfried Kracauer and Karsten Witte (eds.), Kino: Essays, Studien, Glossen zum Film, Frankfurt 1974, pp. 43-45. 
48. Koch (2003, p. 225).

49. Ibid.

50. Benjamin Moldenhauer, "Die Lücken, die das Bild uns lässt: Geschichte, Gewalt und Reflexivität in the act of KILling und L'IMAGe MANQUANTE," in Heinz-Peter Preußer (ed.), Gewalt im Bild: Ein interdisziplinärer Diskurs, Marburg, 2018, p. 391.

51. On apparatus theory, see Philip Rosen (ed.), Narrative, Apparatus, Ideology: A Film Theory Reader, New York 1986.

52. Ibid.

53. Mattias Frey, "The Authenticity Feeling: Language and Dialect in the Historical Film,” 2018, https://film-history.org/approaches/ authenticity-feeling (last accessed May 1, 2020).

54. Ibid.

55. See on this point Roger Odin's proposal of a "documentarizing reading," which is inaugurated not by the reality of what is depicted but the "presupposed reality of the enunciator." Roger Odin, "Dokumentarischer Filmdokumentarisierende Lektüre," in Eva Hohenberger (ed.), Bilder des Wirklichen: Texte zur Theorie des Dokumentarfilms, Berlin 1998, pp. 286-303.

56. On this point, Barthes writes: "Flaubert's barometer, Michelet's little door finally say nothing but this: we are the real; it is the category of 'the real' (and not its contingent contents) which is then signified; in other words, the very absence of the signified, to the advantage of the referent alone, becomes the very signifier of realism: the reality effect is produced, the basis of that unavowed verisimilitude which forms the aesthetic of all the standard works of modernity." Roland Barthes, "The Reality Effect," in his The Rustle of Language, Berkeley 1989, p. 148. Siegfried Kracauer attributes to film images a "reality character" that spectators respond to directly: "First, film records physical reality for its own sake. Struck by the reality character of the resultant images, the spectator cannot help reacting to them as he would to the material aspects of nature in the raw which these photographic images reproduce. Hence their appeal to his sensitivity. It is as if they urged him through their sheer presence unthinkingly to assimilate their indeterminate and often amorphous patterns." Siegfried Kracauer, Theory of Film: The Redemption of Physical Reality, Princeton 1997 , p. 158.

57. Mattias Frey, by reference to Jonathan Stubbs and Vivian Sobchack, speaks of historical films' "qualitative and quantitative excess of detail" that is intended to demonstrate their historicity and is "reconfirmed with perpetual references, both within the films themselves and in extratextual discourse." Frey (2018). 
58. Vincent Bisson, "Historical Film Reception: Mediated Legends," in Kathryn Anne Morey (ed.), Bringing History to Life through Film: The Art of Cinematic Storytelling, Lanham, MD, 2014, p. 139.

59. Roland Barthes, Camera Lucida: Reflections on Photography, New York 1981, pp. 76-77.

60. Although Baron is thinking here mainly of appropriation films (where the use of archival material and found footage plays a significant role), the concept of the archive effect can also be applied to the use of archival material in fictional films. Jaimie Baron, The Archive Effect: Found Footage and the Audiovisual Experience of History, London 2014.

61. "[A] sense of the 'presence' of history"; "our desire for an affective encounter with the past that cannot be reduced to desire for its meaning." Ibid., p. 13.

62. Ibid.

63. Ibid., p. 174.

64. Koch (2003, p. 223).

65. Frey (2018).

\section{BIBLIOGRAPHY}

Béla Balázs, Theory of the Film: Character and Growth of a New Art, Scotts Valley 2015.

Béla Balázs, Visible Man, in Béla Balázs: Early Film Theory, New York and Oxford 2010.

Jaimie Baron, The Archive Effect: Found Footage and the Audiovisual Experience of History, London 2014.

Roland Barthes, "The Problem of Signification in Cinema," in his Signs and Images: Writings on Art, Cinema and Photography, London 2016.

Roland Barthes, "Myth Today" in A Barthes Reader, London 1993, pp. 93-150.

Roland Barthes, The Rustle of Language, Berkeley 1989.

Roland Barthes, Camera Lucida: Reflections on Photography, New York 1981.

Vincent Bisson, "Historical Film Reception: Mediated Legends," in Kathryn Anne Morey (ed.), Bringing History to Life through Film: The Art of Cinematic Storytelling, Lanham, MD, 2014, pp. 135-150.

Robert Burgoyne, The Hollywood Historical Film, Malden, MA, 2008.

Francesco Casetti, Communicative Negotiation in Cinema and Television, Milan 2002.

Jacques Derrida, Of Grammatology Baltimore 2016.

Marc Ferro, Cinema and History, Detroit 1992.

Mattias Frey, "The Authenticity Feeling: Language and Dialect in the Historical Film," 2018, https://film-history.org/approaches/authenticity-feeling (last accessed May 1, 2020). 
Bernhard Groß, Die Filme sind unter uns: Zur Geschichtlichkeit des frühen deutschen Nachkriegskinos: Trümmer-, Genre-, Dokumentarfilm, Berlin 2015.

Matthias Hein, Zu einer Theorie des Erlebens bei Béla Balázs, Würzburg 2011.

Georg G. Iggers, "Die kulturelle und die linguistische Wende," in his Geschichtswissenschaft im 20. Jahrhundert, Göttingen 2007, pp. 101-110.

Gertrud Koch, "Nachstellungen: Film und historischer Moment," in Eva Hohenberger and Judith Keilbach (eds.), Die Gegenwart der Vergangenheit: Dokumentarfilm, Fernsehen und Geschichte, Berlin 2003.

Siegfried Kracauer, Theory of Film: The Redemption of Physical Reality, Princeton 1997.

Siegfried Kracauer, "Der historische Film," in Siegfried Kracauer and Karsten Witte (eds.), Kino: Essays, Studien, Glossen zum Film, Frankfurt 1974, pp. 43-45.

Yuri [Jurij] M. Lotman, Universe of the Mind: A Semiotic Theory of Culture, Bloomington and Indianapolis 1990.

Siegfried Mattl, "Populare Erinnerung: Zur Nahbeziehung von Film und Geschichte," Nach dem Film 15: Das Unsichtbare Kino, 2017, https://nachdemfilm.de/issues/text/populare-erinnerung (last accessed May 1, 2020).

Benjamin Moldenhauer, "Die Lücken, die das Bild uns lässt: Geschichte, Gewalt und Reflexivität in the act of killing und l'image manquante," in Heinz-Peter Preußer (ed.), Gewalt im Bild: Ein interdisziplinärer Diskurs, Marburg 2018, pp. 391-411.

Roger Odin, "Dokumentarischer Film - dokumentarisierende Lektüre," in Eva Hohenberger (ed.), Bilder des Wirklichen: Texte zur Theorie des Dokumentarfilms, Berlin 1998, pp. 286-303.

Jacques Rancière, "Die Geschichtlichkeit des Films," in Hohenberger and Keilbach 2003, pp. 230-246.

Philip Rosen (ed.), Narrative, Apparatus, Ideology: A Film Theory Reader, New York 1986.

Robert A. Rosenstone, "The History Film as a Mode of Historical Thought," in Rosenstone and Parvulescu 2013, pp. 71-87.

Robert A. Rosenstone and Constantin Parvulescu (eds.), A Companion to the Historical Film, Malden, MA, 2013.

Simon Rothöhler, Amateur der Weltgeschichte: Historiographische Praktiken im Kino der Gegenwart, Zurich 2011.

Axel Rüth, Erzäblte Geschichte: Narrative Strukturen in der französischen AnnalesGeschichtsschreibung, Berlin and New York 2005.

Dietrich Scheunemann, "'Fiktionen - auch aus dokumentarischem Material': Von Konstruktionen der Geschichte in Literatur und Film seit den sechziger Jahren," in Hartmut Eggert, Ulrich Profitlich, and Klaus R. Scherpe (eds.), Geschichte als Literatur: Formen und Grenzen der Repräsentation von Vergangenheit, Stuttgart 1990, pp. 296-314. 
Pierre Sorlin, The Film in History: Restaging the Past, Oxford 1980.

Jonathan Stubbs, Historical Film: A Critical Introduction, New York 2013. Eleftheria Thanouli, History and Film: A Tale of Two Disciplines, New York and London 2019.

Margrit Tröhler, "Filmische Authentizität: Mögliche Wirklichkeiten zwischen Fiktion und Dokumentation," montage AV 13:2, 2004, pp. 149-169.

André Wendler, Anachronismen: Historiografie und Kino, Paderborn 2014.

Hayden White, "The Question of Narrative in Contemporary Historical Theory," History and Theory 23:1, 1984.

\section{Filmography}

Ku'damm 56; dir. Sven Bohse; Germany 2016.

Sky without Stars (Himmel ohne Sterne); dir. Helmut Käutner; Federal Republic of Germany 1955.

Years of Hunger (Hungerjahre); dir. Jutta Brückner; Federal Republic of Germany 1980.

Open Access This chapter is licensed under the terms of the Creative Commons Attribution 4.0 International License (http://creativecommons.org/licenses/ by $/ 4.0 /$ ), which permits use, sharing, adaptation, distribution and reproduction in any medium or format, as long as you give appropriate credit to the original author(s) and the source, provide a link to the Creative Commons licence and indicate if changes were made.

The images or other third party material in this chapter are included in the chapter's Creative Commons licence, unless indicated otherwise in a credit line to the material. If material is not included in the chapter's Creative Commons licence and your intended use is not permitted by statutory regulation or exceeds the permitted use, you will need to obtain permission directly from the copyright holder.

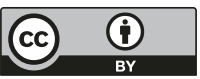

